\title{
Buddha in Disguise: Problems in the Transmission of »Barlaam and Josaphat«
}

In 1591, Jesuit missionaries in Japan produced one of the first books in Japanese to be printed in movable type, albeit in Latin script ${ }^{1}$. What they printed was a compendium of the Acts of the Saints (»Sanctos no Gosagveono Vchinvqigaqi«), which included »The Life of the Blessed Confessors Saint Barlaam and Saint Josaphat« (»Tattoqi Confessores S. Barlan to, S. Iosaphat no gosagueo«). It is the oldest such book, copies of which are still extant today. We have no sources giving the reaction of the Japanese public or mentioning whether this public realized that they were reading a story with which most of them were already familiar. For one of the two seemingly Catholic saints $^{2}$, Josaphat, is in fact none other than Buddha himself ${ }^{3}$. But how did he end up as a Christian saint, presented to a mostly Buddhist public 4 ?

In this article, I will present a stemma according to the present state of research, and will then discuss problems in the transmission of this text, especially addressing the question of the religious background of the people involved. I begin, however, with a summary of the story, according to the longest surviving Arabic form ${ }^{5}$.

The king of India is an idolater and persecutes both asceticism (nusk) and (true) religion $(\operatorname{din})$ and its supporters. He lives an entirely worldly life and is very successful, but despairs of ever having a son. Finally, his favourite wife, after a dream of an ele-

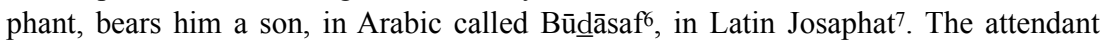

1 See Keiko IKEgAmI, Barlaam and Josaphat. A Transcription of MS Egerton 876 with Notes, Glossary, and Comparative Study of the Middle English and Japanese Versions, New York 1999, esp. p. 31-32, 41, and 44-49. The (Latin) source used has not yet been firmly established (see ibid., p. 55-56).

2 Barlaam and Josaphat were officially added to the »Martyrologium Romanum « in 1583: see Robert VOLK, Johannes von Damaskus. Die Schriften, vol. 6: Historia animae utilis de Barlaam et Ioasaph (spuria), vol. 1: Einführung, Berlin 2009 (Patristische Texte und Studien, 61), p. 15.

3 See below.

4 The text was used by the Jesuit missionaries in (South)East Asia, not only in Japan but also in China, Tamil-Nadu, and the Philippines. See IKEGAMI, Barlaam and Josaphat (as in n. 1), p. 28; VOLK, Johannes von Damaskus (as in n. 2), p. 152-154.

5 There are three Arabic versions extant. For the longest Arabic text, see Daniel GIMARET, Kitāb Bilawhar wa Būdāsf, Beirut 1972; a French translation is available as ID., Le livre de Bilawhar et Būdāasf selon la version arabe ismaélienne, Geneva 1971 (Hautes études islamiques et orientales d'histoire comparée, 3 ). It should be noted that this version cannot claim to be the archetype (see ibid., p. 57).

6 Gimaret always uses the form Būdāsf, in analogy with names of Persian legendary heroes well known to a medieval Arabic-speaking audience such as Luhrāsf, Ğāmāsf etc.: see GIMARET, Le livre de Bilawhar et Būdāsf (as in n. 5), p. 63, n. 4. This form, however, is against the rules of 
astrologers tell the king that his son will be famous, but the wisest and most experienced of them says that, although he will indeed become famous, he will be so for his ascetic religion. The king tries to get around the stars by locking up his son, instructing the servants never to tell him about death and diseases, and not letting him out of the palace, so that the boy will never know of anything unpleasant. But the prince realizes that he is the only person not allowed to leave the palace. Eventually, he gets permission to go riding outside. However, the servants are instructed to clear the streets so that the prince will still not be disturbed by the presence of illness or death. This cannot last: the prince meets a sick man, a blind man, and a very old man. Through these encounters, he becomes aware of sickness and death, and starts to think about the meaning of life. This is when the second protagonist - in Arabic called Bilawhar, in Latin Barlaam ${ }^{8}$ - enters the stage: he is one of the ascetics who had left the country, but he just decided to come back in disguise to save the prince's soul. He starts telling the young man parables about the vanity of the world and the meaning of the afterlife. The prince is easily convinced of the truth of monotheism. After four months, Barlaam takes his leave, just in time, for the king has finally realized that something is going wrong. He tries to win back his son to a worldly life. But whatever he does, he fails: the prince is not tempted by the beauty of women and is not intrigued by foul tricks and magic. Eventually, the prince leaves the world and converts his people to monotheism.

This story goes back to Indian legends about the life of Buddha, though it is impossible to establish a single source 9 . The most striking parallels are the dream of the prince's mother and his encounters with the sick man, the blind man, and the old $\operatorname{man}^{10}$. Another point is his name: the prince gets his name from Bodhisattva, the Buddha in the present world ${ }^{11}$. Finally, the tales told to illustrate the true faith are of Indian,

Arabic syllable structure and not to be found in cases where the manuscripts occasionally indicate the vocalization (ibid.). I therefore keep the more >Arabic « form of Būdāaaf, which also makes the Georgian form of the name (see below, n. 7) more easily understandable.

7 By misspelling, the Arabic Būdāasaf becomes Yū gian. See Ilia V. ABULADZE, Introduction, in: David Marshall LANG, The Balavariani (Barlaam and Josaphat), London 1966, p. 19-41, here p. 29; GIMARET, Le livre de Bilawhar et Būdāsf (as in n. 5), p. 8 and 63. In this article, I generally use the more widely known Latin forms of the proper names.

8 The Arabic Bilawhar (also Balawhar and Bulūhar) becomes Balahvar in Georgian: see ABULADZE, Introduction (as in n. 7), p. 29; GIMARET, Le livre de Bilawhar et Būdāsf (as in n. 5), p. 8 and 63.

9 The most important Indian sources are the »Lalita-vistara« and the »Buddha-carita«. See Philip ALMOND, The Buddha of Christendom. A Review of the Legend of Barlaam and Josaphat, in: Religious Studies 23 (1987), p. 391-406, here p. 396-397; Isabel TORAL-NIEHOFF, Die Legende »Barlaam und Josaphat « in der arabisch-muslimischen Literatur. Ein arabistischer Beitrag zur »Barlaam-Frage«, in: Die Welt des Orients 31 (2000/2001), p. 110-144, here p. 111.

10 See Almond, The Buddha of Christendom (as in n. 9), p. 397; Toni BRÄM, Le roman de Barlaam et Josaphat, in: Richard Goulet (ed.), Dictionnaire des philosophes antiques, vol. 2, Paris 1994, p. 63-83, here p. 71-72; IKEGAMI, Barlaam and Josaphat (as in n. 1), p. 14-15.

11 Barlaam (Arabic Bilawhar), on the other hand, seems to derive from the Indian Bhagavan (»Master $\ll$ ), which fits his role very well, but this etymology has not yet been proved: see Wal- 
mostly Buddhist origin ${ }^{12}$. The most important differences are that the real Buddha did not need a teacher ${ }^{13}$ to understand the truth and that his teaching was not about monotheism ${ }^{14}$.

What happened between the two points mentioned so far - the starting point in India and the endpoint in a Jesuit text for a Japanese public? From India, the Buddha legend travelled to the Arabic-speaking world. There are three Arabic versions of the »Barlaam« story extant today: the so-called Ismaili version, edited by Daniel Gimaret, being the longest; a version included in the work »Ikmāl [or Kamāl] ad-dīn wa-tamām an-ni'ma« by the Twelver Shiite Ibn Bābūya (d. 381/991); and a shortened and only incompletely transmitted version known as the Druze or Halle version ${ }^{15}$. The dating of these Arabic versions poses some problems. All Arabic manuscripts containing the texts are - as usual in the transmission of Arabic literary texts - rather late. For the so-called Ismaili version, they are nineteenth century ${ }^{16}$; the manuscripts of Ibn Bābūya's »Ikmāl ad-dīn« are mostly from the sixteenth and seventeenth centuries ${ }^{17}$; and, of the two manuscripts of the so-called Druze version, one is dated to 1099/168718. As Ibn Bābūya died in $381 / 991$, this version of the »Barlaam« must have circulated before the end of the tenth century. Furthermore, if we are to take his indications of his sources seriously, as I think we should, we are led back even further, to the early tenth century ${ }^{19}$. As the Georgian version translated from Arabic seems to date from before $900^{20}$, this gives us

ter B. HenNING, Sogdian Tales, in: Bulletin of the School of Oriental and African Studies 11 (1945), p. 465-487, here p. 487.

12 See E. A. Wallis Budge, Baralâm and Yewâsef, Being the Ethiopic Version of a Christianized Recension of the Buddhist Legend of the Buddha and the Bodhisattva, vol. 2: Introduction, English translation, etc., Cambridge 1923, p. xix-xxvii; ALMOND, The Buddha of Christendom (as in n. 9), p. 398; IKEGAMI, Barlaam and Josaphat (as in n. 1), p. 16-17. For a different view, see Daniel GIMARET, Traces et parallèles du Kitāb Bilawhar wa Būdāsf dans la tradition arabe, in: Bulletin d'études orientales 24 (1971), p. 97-133, here p. 97, n. 2.

13 It was argued that the figure of Barlaam most clearly shows the Manichean origins of the »Barlaam«, as the Manicheans insisted on the importance of anybody aspiring for religious truth to have a teacher from among the electi. See ALMOND, The Buddha of Christendom (as in n. 9), p. 405-406; TORAL-NIEHOFF, Die Legende »Barlaam und Josaphat« (as in n. 9), p. 113. It should be noted, however, that the idea already exists in Buddhism that a teacher figure, most notably a Bodhisattva, will help humankind on its way to enlightenment; moreover, in classical Islam, the mystical novice searching for God will be under the guidance of a teacher $(\check{s} a y h)$. See Eric GEOFFroy, Shaykh, in: The Encyclopaedia of Islam 2, Leiden 1960-2004, vol. 9 (1996), p. 397-398.

14 See ALmOND, The Buddha of Christendom (as in n. 9), p. 398.

15 For a discussion of the (religious) background of these Arabic versions, see below.

16 See Gimaret, Le livre de Bilawhar et Būdāsf (as in n. 5), p. 9-10; ID., Kitāb Bilawhar wa Būdāâff (as in n. 5), p. 11-17.

17 Fuat SEZGIN, Geschichte des arabischen Schrifttums, vol. 1: Qur'ānwissenschaften, Hadīt, Geschichte, Fiqh, Dogmatik, Mystik. Bis ca. 430 H, Leiden 1967, p. 548-549, indicates around 20 manuscripts, for 15 of which he gives a date. Of these, thirteen are from the eleventh/sixteenth-seventeenth centuries, one from the tenth/sixteenth century, and one from the ninth/fifteenth century.

18 See Gimaret, Le livre de Bilawhar et Būdāsf (as in n. 5), p. 26.

19 Ibid., p. 32-35; and see also below.

20 See ABuladZE, Introduction (as in n. 7), p. 32, 35-36. 
some indication as to the terminus ante quem. On the other hand, the attribution of a versification of the text to the late eighth-century poet Abān al-Lāhiqīi, as found in Ibn an-Nadīm's »Fihrist « (completed in 377/987-988) 21, is probably wrong: it seems that this and other versifications were attributed to Abān well after his lifetime ${ }^{22}$. Nevertheless, the style of the Ismaili text suggests a relatively early date of translation. Gimaret has suggested a date between 750 and 900, with an inclination towards the earlier part of that period, namely the second half of the eighth century, which to me seems quite probable ${ }^{23}$. How the »Barlaam « eventually arrived in the Arabic-speaking world and what intermediaries were involved is discussed below.

From Arabic, the text moved in several directions: into Georgian ${ }^{24}$, Hebrew ${ }^{25}$, New Persian $^{26}$, and Castilian ${ }^{27}$. From the Hebrew, we have a line towards Yiddish ${ }^{28}$ and Judeo-Persian ${ }^{29}$, but, unlike so many other medieval texts, no other continuation and markedly none into Latin. Amazingly, the Georgian version, which seems to have been produced before 900, was far more influential ${ }^{30}$. It served as Vorlage not only for an abbreviated version ${ }^{31}$ but also for a Byzantine Greek translation of the second half of the tenth century ${ }^{32}$. From Greece, the story eventually conquered both East and West ${ }^{33}$. Among others, we have a translation back into Arabic (this time a Christian form of it) ${ }^{34}$ and several translations into Latin. And it is in Latin that we see the story become

21 Ibn an-Nadīm, Kitāb al-fihrist, ed. Gustav FLÜGEL, Leipzig 1871-1872 (reprinted Beirut 1964), p. 119, 163.

22 See Iḥsān 'ABBĀs, Abān b. 'Abd al-Hamīd b. Lāheq, in: Ehsan YARSHATER (ed.), Encyclopaedia Iranica, London, New York 1985-, vol. 1 (1985), p. 58-59; Tilman SEIDENSTICKER, Abān al-Lāhiqīi, in: Kate FLEET, Gudrun KRÄMER et al. (eds.), Encyclopaedia of Islam 3, Leiden 2007, fasc. 2007-2, p. 2-3.

23 See GiMARET, Le livre de Bilawhar et Būdāsf (as in n. 5), p. 61.

24 See below.

25 A translation in rhymed prose by Abraham ibn Hasday of Barcelona (d. 1240): see GIMARET, Le livre de Bilawhar et Būdāsf (as in n. 5), p. 47-50.

26 The fourteenth-century version by Nizāām ad-Dīn Šāmī: see ibid., p. 43-47.

27 See Franz BRUNHÖLZL et al., Barlaam und Joasaph, in: Lexikon des Mittelalters, Stuttgart [1977]-1999, vol. 1 (1980), col. 1464-1469, 1466.

28 See Wulf-Otto DrEessen, Ben ha-melech weha-nosir, in: Die deutsche Literatur des Mittelalters. Verfasserlexikon, Berlin, New York 1978-2004, vol. 1 (1978), col. 686-687.

29 See Gimaret, Le livre de Bilawhar et Būd̄āsf (as in n. 5), p. 47-48; Jürgen TuBACH, Das Bild vom idealen Christen. Askese im Barlaam-Roman, in: Armenuhi Drost-ABGARJAN, Jürgen TuBACH (eds.), Sprache, Mythen, Mythizismen. Festschrift Walter Beltz, vol. 3, Halle 2004, p. 759-782, here p. 764.

30 See above, n. 20. English translation: David Marshall LANG, The Balavariani (Barlaam and Josaphat), London 1966.

31 See TORAL-NiEHOFF, Die Legende »Barlaam und Josaphat« (as in n. 9), p. 126.

32 For many years this version was attributed to John of Damascus (see below). Edition: Robert VoLK, Johannes von Damaskus. Die Schriften, vol. 6: Historia animae utilis de Barlaam et Ioasaph (spuria), 2 vols., Berlin 2006-2009 (Patristische Texte und Studien, 60-61).

33 For a general overview, see BRUNHÖLZL et al., Barlaam und Joasaph (as in n. 7).

34 See Jules Leroy, Un nouveau manuscrit arabe-chrétien illustré du Roman de Barlaam et Joasaph, in: Syria 32 (1955), p. 101-122; Sylvia AGÉMIAN, Deux manuscrits arabes chrétiens illustrés du Roman de Barlaam et Joasaph, in: Revue des études arméniennes 23 (1992), p. 577-601; Johannes PAHLITZSCH, Graeci und Suriani im Palästina der Kreuzfahrerzeit. Bei- 
most influential. Three independent Latin prose versions were produced between the eleventh and the sixteenth centuries. The oldest translation is from 1048, extant in a single manuscript, and seems not to have made a lasting impression ${ }^{35}$. From the twelfth century onwards, a different Latin translation became widespread, the so-called $»$ Vulgate $« 36$. Its origin seems to have been northern France, and it served as the basis for several short versions and excerpts, most notably the renderings of the »Barlaam « included by Vincent de Beauvais in his »Speculum Historiale « ${ }^{37}$ and by Jacobus de Voragine in the $»$ Legenda Aurea ${ }^{38}$. A third Latin translation was made by Jacques de Billy, abbot of the Benedictine monastery of Saint-Michel de 1'Herm in the Vendée ${ }^{39}$. It is this version, dating from 1577, that was reprinted in Migne's »Patrologia Latina « ${ }^{40}$. One final version is supplied by a Latin versification from the twelfth century ${ }^{41}$.

From Latin, the story continues: we have versions in most European vernaculars, including French and Provençal, the languages of the Iberian Peninsula, Italian, Czech, Polish, Russian, German, English, and several Scandinavian languages ${ }^{42}$. And it is somewhat ironic that the Latin text was also translated back into Greek ${ }^{43}$. The Japanese version mentioned in the introduction probably goes back to a Latin one as well ${ }^{44}$.

träge und Quellen zu Geschichte des griechisch-orthodoxen Patriarchats von Jerusalem, Berlin 1998 (Berliner historische Studien, 33; Ordensstudien, 15), esp. p. 278-280; TORAL-NIEHOFF, Die Legende »Barlaam und Josaphat« (as in n. 9), p. 128. The Christian Arabic version was later translated into Ethiopian: see BUDGE, Baralâm and Yewâsef (as in n. 13).

35 Edition: José MARTíNEZ GÁZQUEZ, Hystoria Barlae et Iosaphat (Biblioteca Nacional de Nápoles VIII.B.10), Madrid 1997 (Nueva Roma, Bibliotheca Graeca et Latina Aevi Posterioris, 5). See also Jean SONET, Le roman de Barlaam et Josaphat, vol. 1: Recherches sur la tradition manuscrite latine et française, Namur, Paris 1949 (Bibliothèque de la Faculté de Philosophie et Lettres de Namur, 6), p. 63-64; Óscar DE LA CRUZ PALMA, Barlaam et Iosaphat. Versión vulgata latina con la traducción castellana de Juan de Arce Solorceno (1608), Madrid, Bellaterra 2001 (Nueva Roma, 12), p. 34; VOLK, Johannes von Damaskus (as in n. 2), p. 144; Matthias FISCHER, Versus de Sanctis Barlaam et Josaphat. Die anonyme Versifikation der Barlaam- und Josaphatlegende (12. Jh.) in der Handschrift Besançon BM 94, Bern 2003 (Lateinische Sprache und Literatur des Mittelalters, 37), p. 11. This translation was made by the Norman Argyros, duke of Italy, who spent five years in Constantinople around the middle of the eleventh century. Argyros seems to have obtained his Greek Vorlage from a man called Leon, who might well have been a Latin monk from the Amalfi monastery at Athos.

36 Edition: DE LA CRUZ PALmA, Barlaam et Iosaphat (as in n. 36). Cf. VolK, Johannes von Damaskus (as in n. 2), p. 144-145; SONET, Le roman de Barlaam et Josaphat (as in n. 35), p. 76-88; FISCHER, Versus de Sanctis Barlaam et Josaphat (as in n. 35), p. 11-12.

37 See DE La Cruz PALma, Barlaam et Iosaphat (as in n. 35), p. 37-38.

38 Ibid., p. 38-39.

39 See VolK, Johannes von Damaskus (as in n. 2), p. 13.

40 Jacques-Paul Migne (ed.), Patrologiae cursus completus. Patrologia latina, vol. 73: Vitae patrum sive historiae eremiticae libri decem, Paris 1879 (reprinted Turnholt 1967), col. 443604.

${ }^{41}$ Edition: FISCHER, Versus de Sanctis Barlaam et Josaphat (as in n. 35).

42 See BRUNHÖLZL et al., Barlaam und Joasaph (as in n. 27).

43 See VolK, Johannes von Damaskus (as in n. 2), p. 144; Wassilios KLEIN, Die Legende von Barlaam und Ioasaph als Programmschrift des Mönches Agapios Landos, Hamburg 1997.

44 See above, n. 1. 
But who were the intermediaries between the Indian Buddha legend and the Arabic archetype ${ }^{45}$ ? What do we know about the Arabic versions, especially about the milieux of their production and transmission? And when did the legend of Buddha turn into the life of two Christian saints?

\section{INTERMEDIARIES BETWEEN THE INDIAN BUDDHA LEGEND AND THE ARABIC ARCHETYPE}

How did the story get from India to Iraq, where in all probability the oldest Arabic form should be located? Two ways of transmission have been argued for in »Barlaam« scholarship. Here I propose a slightly different third one.

The first way of transmission is via the Manicheans of Central Asia ${ }^{46}$. This hypothesis is based on fragments found in the Oasis of Turfan ${ }^{47}$, most importantly one in Old Turkish ${ }^{48}$ and one in New Persian ${ }^{49}$. These fragments use names for the protagonists that are close to the Arabic forms. From these findings, the hypothesis is drawn that the »Barlaam« was brought to Central Asia by Buddhists - who are known to have been present in Turfan - and was adapted there by Manicheans. The Manicheans would have loved the story for its appraisal of asceticism and for its parables ${ }^{50}$. From Turfan, the story would then have moved on to the West, arriving in Baghdad, where it was translated into Arabic. However, this theory has its weaknesses. The main one is that this way of transmission is not attested with any other text. Furthermore, the very convincing New Persian fragment is considerably later than the Arabic archetype, as it dates from the first half of the tenth century ${ }^{51}$, while the Arabic archetype probably

45 I do not mean to suggest that it is possible to reconstruct such an archetype, as the extant versions are too far apart from each other. By the use of this term, I simply wish to imply that there must have been an rearliest` Arabic text at some point, though we cannot be sure about its form, date, etc.

46 See TORAL-NiEHOFF, Die Legende »Barlaam und Josaphat« (as in n. 9), p. 111-113.

47 TuBACH, Das Bild vom idealen Christen (as in n. 29), p. 760, mentions a Parthian version, referring to W[alter] B. HENNING, Die älteste persische Gedichthandschrift. Eine neue Version von Barlaam und Joasaph, in: Herbert FrANKE (ed.), Akten des vierundzwanzigsten internationalen Orientalisten-Kongresses München, Wiesbaden 1959, p. 305-307; ID., Persian Poetical Manuscripts from the Time of Rūdakī, in: A Locust's Leg. Studies in Honour of S. H. Taqizade, London 1962, p. 89-104, but I have not been able to find a reference to a Parthian version in Henning's articles.

48 Published by Albert von LE COQ, Ein christliches und ein manichäisches Manuskriptfragment in türkischer Sprache aus Turfan (Chinesisch-Turkistan), in: Sitzungsberichte der Königlich Preussischen Akademie der Wissenschaften, Phil.-hist. Classe, 2. Halbbd. (1909), p. 12021218.

49 Published by Henning, Persian Poetical Manuscripts (as in n. 47), p. 91-98.

50 See TORAL-NiEHOFF, Die Legende »Barlaam und Josaphat« (as in n. 9), p. 113; for the potential Manichean background of the Barlaam figure, see above, n. 13.

51 See Henning, Persian Poetical Manuscripts (as in n. 47), p. 91-98. 
goes back to a time before 900 , maybe even to the second half of the eighth century ${ }^{52}$. Finally, even the Turkish fragment might be later than the Arabic: it need not be a version of the »Barlaam « proper, but could, I think, represent a version of any form of the Buddha legend, as the fragment does not include anything specific to the »Barlaam» tradition that would be lacking in the Indian Buddha legends ${ }^{53}$.

The second hypothesis concerning the way of transmission to Iraq is that the Indian legend or rather legends were translated into Middle Persian and thence into Arabic, as was done with other texts, most notably with the famous »Kalīla wa-Dimna «54. This hypothesis has the big advantage that it gives a well known parallel. But it has some disadvantages, mainly, that we have no trace or indication at all of a Middle Persian version of the »Barlaam «.

I would like to propose a third option: that the Buddha legend travelled in both directions, East and West, independently. This hypothesis would explain the Turkish fragment from Turfan as an independent translation from an Indian source, while the Persian fragment might still go back to the Arabic archetype, as has already been suggested by the editor of this fragment ${ }^{55}$. The way westwards to Iraq need not have been via Middle Persian. In fact, we should dare to ask the question whether we need an intermediate language. It must be admitted that there are not many translations of Indian texts into Arabic, but there are some: for example of astrological works ${ }^{56}$, but especially in the field of medicine. Many medical translations date from precisely the time under discussion, namely the second half of the eighth century, and also come from the place in question, namely Iraq ${ }^{57}$. Clearly there were people in Iraq with some knowledge of Indian languages, and we might assume that they were not only interested in medical writings. However, I admit that there is no proof for this hypothesis at present.

\section{ARABIC VERSIONS - A SECTARIAN MILIEU?}

As we have noted above, we have three Arabic versions of the text extant in manuscripts, and all of them are connected with a sectarian milieu. First, there is the socalled Ismaili version, edited by Gimaret, the longest of the Arabic texts, and probably the closest to the archetype ${ }^{58}$. Second, a version is included in the work »Ikmāl [or Kamāl] ad-dīn wa-tamām an-nicma« by the Twelver Shiite Ibn Bābūya who gives us

52 See Gimaret, Le livre de Bilawhar et Būdāsf (as in n. 5), p. 61, n. 11; TORAL-NiEHOFF, Die Legende »Barlaam und Josaphat« (as in n. 9), p. 113.

53 See Gimaret, Le livre de Bilawhar et Būdāsf (as in n. 5), p. 61, n. 11.

54 See TORAL-NIEHOFF, Die Legende »Barlaam und Josaphat $«$ (as in n. 9), p. 113-114.

55 See Henning, Die älteste persische Gedichthandschrift (as in n. 47), p. 307.

56 See Manfred UllmanN, Die Natur- und Geheimwissenschaften im Islam, Leiden 1972 (Handbuch des Orientalistik, 1. Abt., Ergänzungsbd. 6,2), p. 300-301.

57 Cf. Manfred Ullmann, Die Medizin im Islam, Leiden 1970 (Handbuch der Orientalistik, 1. Abt., Ergänzungsbd. 6,1), p. 103-107.

58 Edition: GIMARET, Kitāb Bilawhar wa Būdāasf (as in n. 5). 
the names of his sources, which lead back to the Shiite milieu of the southern Iraqi town of Basra in the early tenth century ${ }^{59}$. This version does not mention the king's tricks to win back his son; instead, we get even more discussions between Barlaam and Josaphat, and three more, longish parables ${ }^{60}$. Finally, there is the short form (muhtașar) transmitted in an incomplete Druze manuscript kept in Halle and, even more incomplete, in a Cairo manuscript ${ }^{61}$. This short form obviously goes back to the so-called Ismaili version edited by Gimaret ${ }^{62}$ and, if we consider the strong link between the Ismailis and the Druze, this cannot come as a surprise ${ }^{63}$.

This evidence seems to suggest that the Arabic »Barlaam« was not a widely read text ${ }^{64}$, that it was probably translated in a sectarian milieu, and that it remained within these circles, always being considered a non-mainstream piece of literature. But is this assumption correct? If we look for citations in Arabic literature, we find some in the catalogue of the tenth-century Baghdadi bookseller Ibn an-Nadīm. He mentions several titles, of which two seem to designate versions of the »Barlaam«, but he gives no indication of a problematic milieu ${ }^{65}$. As his attribution of a versification to the eighthcentury poet Abān al-Lāhiqīi, who had a reputation for Manichean tendencies, seems to be wrong66, a sectarian milieu has no more probability than any other. On the other hand, the connection to an Ismaili and therefore a >heterodox ‘ milieu is now generally acknowledged for a famous tenth-century encyclopaedia, the »Rasā̄il Ihwān aṣ-

59 See Gimaret, Le livre de Bilawhar et Būdāsf (as in n. 5), p. 27-35. Ibn Bābūya's chain of transmitters $(i s n \bar{a} d)$ names as ultimate source an expert in tradition from Basra, Abū 'Abdallāh Muhammad b. Zakariyyā’ b. Dīnār al-Ǧawharī al-Ġalabī al-Bașrī (d. 298/911), who is known for his Shiite tendency, as well as for being an author of literary works (adab). However, he might not have been a strict Twelver Shiite, as he also transmits traditions about Muhammad an-Nafs az-Zakiyya and about Muhammad's brother Zayd (see Abū 'l-Farağ al-Ișfahānī, maqātil aț-țālibiyyīn, ed. Aḥmad SAQR, Cairo 1368/1949, p. 239-240, 367). I wish to thank Gerald Grobbel (Zurich) for these references. The »Ikmāl ad-dīn « was lithographed in Teheran 1301/1884 (the »Barlaam « is on p. 317-360); there are also more recent typeset editions, e.g. Abū Ğacfar Muhammad b. 'Alī Ibn Bābūya, Kamāl ad-dīn, ed. 'Alī Akbar AL-ĠAfFāRĪ, Teheran $1395 \mathrm{H}$. (the »Barlaam« is in vol. 2, p. 577-639).

60 See Gimaret, Le livre de Bilawhar et Būdāsf (as in n. 5), p. 24, 29-30; Samuel Miklos STern, Sofie WALzER, Three Unknown Buddhist Stories in an Arabic Version, Oxford 1971 (with edition and English translation).

61 Edition: Fritz HommeL, Die älteste arabische Barlaam-Version, in: Verhandlungen des VII. Internationalen Orientalisten-Congresses, Sem. Section, Wien 1887, p. 115-165. See also GIMARET, Le livre de Bilawhar et Būdāsf (as in n. 5), p. 25-26.

62 See Gimaret, Le livre de Bilawhar et Būdāsf (as in n. 5), p. 27.

63 The Druze were originally an Ismaili sect who then developed into a religious community of their own. See Marshall G. S. Hodgson, Durūz (i), in: The Encyclopaedia of Islam 2, Leiden 1960-2004, vol. 2 (1963), p. 631-634.

64 Gimaret, Traces et parallèles (as in n. 12), p. 131, by looking for citations of the text in a vast number of Arabic prose works, comes to the same conclusion (»[...] le $K$ [itāb] Bilawhar est resté pratiquement inconnu de la tradition arabe musulmane«), though he might be exaggerating somewhat.

65 Ibn an-Nadīm, Kitāb al-fihrist (as in n. 21), p. 305.

${ }^{66}$ See above, esp. n. 21 and n. 22. 
șafă $^{67}$, in which Bilawhar/Barlaam and Būdāasaf/Josaphat are named several times, and which also cites some of the parables ${ }^{68}$. But as the »Rasầil« cite more or less any work of Arabic literature available in tenth-century Iraq, this does not make a sectarian background for the translation of the »Barlaam» any more probable than any other background, but only demonstrates that the text was being used in Ismaili circles from at least the tenth century.

Far more interesting, therefore, is a remark from the eleventh century, in which Josaphat is called a false prophet ${ }^{69}$. This note is by a most >orthodox< scholar, 'Abd alQāhir al-Baġdādī (d. 429/1037), who seems to be critical of anything that does not fit his worldview ${ }^{70}$. Consequently, it is not surprising that he should disapprove of Josaphat, who could not claim any religious authority in Islamic terms. What is of interest to us, however, is that his criticism clearly shows that the »Barlaam « was readily available in the eleventh century. As it is hard to imagine 'Abd al-Qāhir al-Baġdādī searching for the text among the heterodox, it appears that the text was available more widely. The evidence for a sectarian background is therefore be weak.

More evidence may be found by looking at the text itself. What we find is a story praising an ascetic way of life, but not a form of Islamic asceticism. This was, I think, simply not what most readers wanted. We should take a look at another text of Indian background that became extremely popular indeed, namely »Kalīla wa-Dimna«. This book is an example of fine Arabic prose, and was always considered to be so $^{71}$. Unlike the »Barlaam«, it is not a religious book but a mirror for princes, giving ethical rules for a worldly public, for rulers, princes, and courtiers. This kind of audience did not want to hear praise of an ascetic life. Why should they want to be told that they should get rid of their power and easy life as soon as possible? On the other hand, why should

67 I am inclined to date the »Rasā'il« to between 328/940 and 348/960: see Regula FORSTER, Das Geheimnis der Geheimnisse. Die arabischen und deutschen Fassungen des pseudoaristotelischen »Sirr al-asrār«/»Secretum secretorum«, Wiesbaden 2006 (Wissensliteratur im Mittelalter, 43), p. 18-19. For the Ismaili origin of the »Rasāil« and their dating, see Yves MARQUET, Ikhwān al-Șafă', in: The Encyclopaedia of Islam 2, Leiden 1960-2004, vol. 3 (1970), p. 1071-1076; Farhad DAFTARY, Ismaili Literature. A Bibliography of Sources and Studies, London 2004, p. 166.

68 See Gimaret, Le livre de Bilawhar et Būd̄āsf (as in n. 5), p. 36-38.

69 'Abd al-Qāhir b. Tāhir at-Tamīmī al-Bag̀dādī, al-farq bayn al-firaq, no editor, Beirut 1393/1973, p. 333; English translation: Abraham S. HALKIN, Moslem Schisms and Sects (AlFark Bain al-Firak). Being the History of the Various Philosophic Systems Developed in Islam by Abū-Mansūr 'Abd-al-Kāhir ibn Ṭāhir al-Baghdādī (d. 1037), part 2, Tel Aviv 1935 (reprinted Philadelphia 1978) (Studies in Islamic History, 1), p. 240; see also David M. LANG, The Life of the Blessed Iodasaph. A New Oriental Christian Version of the Barlaam and Ioasaph Romance (Jerusalem, Greek Patriarchal Library: Georgian MS 140), in: Bulletin of the School of Oriental and African Studies 20 (1957), p. 389-407, here p. 391; TORAL-NiEHOFF, Die Legende »Barlaam und Josaphat « (as in n. 9), p. 118.

70 See Arthur S. TRITTON, al-Baghdādī, 'Abd al-Ḳāhir b. Țāhir, Abū Manșūr al-Shāfíî̀, in: The Encyclopaedia of Islam 2, Leiden 1960-2004, vol. 1 (1960), p. 909.

71 See, for example, Carl Brockelmann, Kalīla wa-Dimna, in: The Encyclopaedia of Islam 2, Leiden 1960-2004, vol. 4 (1974), p. 503-506 (originally published in German in: Enzyklopaedie des Islam. Geographisches, ethnographisches und biographisches Wörterbuch der muhammedanischen Völker, Leiden 1913-1936, vol. 2 (1927), p. 744-748). 
pious people have bothered with a text that was not Islamic and hardly made any reference to anything Islamic ${ }^{72}$ ? We have a considerable number of religious Islamic texts from even the eighth century - who needed a non-Islamic one? This is, I argue, where the so-called sects come in: they were ready to keep a non-Islamic text because they were only too happy to prove their point with whatever they could find. Ismailis, Twelver Shiites, Druzes - all of them were, for most of their history, on the fringes of Muslim society and not in power. They therefore tried to argue their point, within and outside their communities. Particularly for arguing outside the community, a text that did not explain too clearly what it meant could be helpful13.

My hypothesis therefore is that the Arabic archetype of the »Barlaam« is not connected with a sectarian milieu. It might have been translated in an >orthodox Sunni milieu, perhaps by somebody hoping, by this new translation of an Indian narrative, to emulate the fabulous success of »Kalīla wa-Dimna«. But the book was not very successful, because some potential readers, namely courtiers, had no interest in asceticism, while others, especially the pious, though interested in asceticism ${ }^{74}$, were not interested in a non-Islamic form of it ${ }^{75}$. While produced in a non-sectarian milieu, the text was eventually only transmitted in sheterodox ( milieux, because only these groups had a special interest in it: they saw their own ideas represented here, especially in view of the text's stress on (secret) mission ${ }^{76}$.

\section{CHRISTIANIZATION}

From Arabic, the text was translated - or rather transferred - into Georgian ${ }^{77}$, probably before 900 and maybe in Jerusalem, where a large Georgian community was involved in translating texts from Arabic into Georgian, especially in the fields of hagiography,

72 It is important to note that the Arabic versions bear very few indications of any connection to Islam: see TORAL-NIEHOFF, Die Legende »Barlaam und Josaphat« (as in n. 9), p. 122-123.

73 In this respect, we can compare the »Barlaam« with a book written by an Ismaili missionary of the tenth century, the »Kitāb al-'Ālim wa-'l-g̉ulām« (edition and English translation: James W. MORRIS, The Master and the Disciple. An Early Islamic Spiritual Dialogue, London 2001). In both books, we only get an idea of what is supposed to be true; furthermore, both books have a very strong focus on the exclusiveness of knowledge and the idea that some are worthy to obtain it, while others are not.

74 One should bear in mind that asceticism per se was not an uncommon ideal for many early Sunnis: see Geneviève GoBILLOT, Zuhd, in: The Encyclopaedia of Islam 2, Leiden 1960-2004, vol. 11 (2002), p. 559-562; Christopher MELCHERT, Asceticism, in: Encyclopaedia of Islam 3, Leiden 2007, fasc. 2007-1, p. 163-169.

75 For a different perspective, see TORAL-NIEHOFF, Die Legende »Barlaam und Josaphat « (as in n. 9), p. 118-120, who argues that the work was unacceptable to a Sunni audience both because of its Manichean origin and because of its asceticism.

76 See ibid., p. 120-122.

77 None of the extant Arabic versions can be established as the single source, as the Georgian translator obviously used a text that was sometimes closer to the so-called Ismaili version and sometimes closer to the one transmitted by Ibn Bābūya. See GiMARET, Le livre de Bilawhar et Būdāsff (as in n. 5), p. 53. 
ascetics, and exegesis ${ }^{78}$. There are two Georgian versions extant: a long one and a short one obviously derived from the long form. These versions are quite exceptional, for what the anonymous Georgian - presumably a monk - produced was by no means a straightforward translation: he systematically adapted the general monotheistic teachings of the Arabic work to the Christian dogma. Josaphat, the prince, does not become convinced of monotheism and of an ascetic way of life in general; rather, he becomes a Christian and is baptized by his spiritual father, Barlaam ${ }^{79}$.

While Georgian was a relatively marginal language, the translation into Byzantine Greek guaranteed the increasing success of the text, adding much theological material and quotations from Scripture, which seem to have helped rather than hindered the diffusion of the story. The Greek version was long attributed to John of Damascus, an attribution impossible on chronological grounds, as John died around 750. The translator into Greek may have been Euthymius Hagiorite, a Georgian monk and later abbot of the Georgian convent of Mount Athos, who died in 1028 and is attested as the translator of the »Barlaam« by several sources ${ }^{80}$.

\section{CONCLUSION}

Who were the agents involved in this complex process of cultural transfer? Whether we should or should not assume Manicheans to have played an important role is a question not yet solved. I believe, however, that their role may have been exaggerated considerably. The story could have reached Iraq quite easily by other ways, be it via Middle Persian or directly from India via merchants, doctors, and the like. However, even after being translated into Arabic, presumably by a Muslim, the text was never Islamized. We can argue that this was one of the reasons for its failure to remain or become widely popular. Later, the text was lost to the general public and was only transmitted in sectarian Muslim communities, such as Ismailis, Twelver Shiites, and Druze, who kept the text for several reasons: for edification, for entertainment, and perhaps for missionary purposes ${ }^{81}$.

It was only with its Christianization that the »Barlaam« became a bestseller. This was most probably due to a Georgian monk from Jerusalem, as the text would fit into the corpus of works translated by the Georgian community in Jerusalem, who were interested in hagiography, ascetics, and exegesis. While only the Byzantine version

78 See ABuladze, Introduction (as in n. 7), p. 39-40; GiMARET, Le livre de Bilawhar et Būdāaf (as in n. 5), p. 50-54.

79 Gimaret, Le livre de Bilawhar et Būdāsf (as in n. 5), p. 52, thinks that the Christianization is fairly discreet, as references to Scripture are relatively infrequent, but these elements are still striking when compared to the next-to-non-existent Islamic features of the Arabic versions.

80 This seems to be his only translation from his native language, Georgian, into Greek, all his other translations being the other way round. See BRÄM, Le roman de Barlaam et Josaphat (as in n. 10); VOLK, Johannes von Damaskus (as in n. 2), esp. p. 74.

81 See TORAL-NIEHOFF, Die Legende »Barlaam und Josaphat« (as in n. 9), p. 120-122. 
definitely stems from a monastic background, we are on fairly safe grounds in arguing that this was also true for the Georgian version.

In the West, the »Barlaam« never entirely left the sphere of hagiography and of pious education. The hagiographic and edifying background, and the missionary ideals present in the »Barlaam«, must have been the reason why it was attractive for the Jesuits in Japan. But we also have a couple of versions in European vernaculars that seem to be intended for a courtly readership. And, while the courtiers of Baghdad seem to have disliked the text deeply, those of medieval Germany loved it and made the version by Rudolf of Ems one of the more popular verse epics of the thirteenth century ${ }^{82}$.

82 For the possible courtly audience of Rudolf's »Barlaam und Josaphat«, see BRUNHÖLZL et al., Barlaam und Joasaph (as in n. 27), col. 1468; Ulrich Wyss, Rudolfs von Ems »Barlaam und Josaphat« zwischen Legende und Roman, in: Peter F. GANZ, Werner ScHRÖDER (eds.), Probleme mittelhochdeutscher Erzählformen. Marburger Colloquium 1969, Berlin 1972, p. 214-238, esp. p. 221-222 and 229-230. The overall popularity is well attested by the fact that a large number of manuscripts (47) of Rudolf's work are extant: see Wolfgang WALLICZEK, Rudolf von Ems, in: Die deutsche Literatur des Mittelalters. Verfasserlexikon, Berlin, New York 1978-2004, vol. 8 (1992), col. 322-345, 329-330. 